\title{
Peningkatan Minat Baca Anak Melalui Pojok Baca Purnama Desa Gemulung Kecamatan Pecangaan Kabupaten Jepara
}

\author{
Muh. Shofiyuddin*, Fatimah Tuzzakiyah, Khusni Faidul Barokah, \\ Dila Ayu Rindiani, Gina Sonia Failasifa, Rona Nur Rifqia, Muhammad Nofan Zulfahmi \\ Universitas Islam Nahdlatul Ulama Jepara \\ *Corresponding Email: muh_shofiyuddin@unisnu.ac.id
}

\begin{abstract}
ABSTRAK
Secara umum dapat diketahui bahwa minat baca dan kemampuan membaca anak-anak di Indonesia masih rendah ketika di bandingkan dengan negara berkembang lainya. Dengan permasalahan minat baca anak yang rendah, maka perlu adanya solusi untuk masyarakat tentunya untuk anak-anak agar minat membacanya tinggi. Dalam meningkatkan minat baca anak, maka Tim Kuliah Kerja Nyata (KKN) UNISNU Jepara Kelompok 27 Mitra Pecangaan memilih sebuah program dengan mitra Pojok Baca Purnama tepatnya di Desa Gemulung RT.03 RW.01 dengan program minat pojok baca ini Tim KKN 27 memberikan literasi dan pendampingan belajar membaca berhadiah, edukasi, dan bermain sehingga minat baca anak semakin meningkat dengan adanya selingan atau literasi yang edukatif sehingga belajar dengan bermain ini dengan tujuan anak minat bacanya semakin meningkat. Apalagi di masa pandemic seperti ini anak yang meraa bosan dengan banyak tugas yang diberikan oleh gurunya Pojok Baca Purnama adalah salah satu tempat mereka kunjungi untuk alasan agar anak tidak bosan dengan tugas sekolah . sehingga dapat disimpulkan bahwa program Pojok Baca Purnama di Desa Gemulung ini dikatakan berhasil karena minat membaca anak semakin meningkat dengan adanya kegiatan membaca berhadiah, literasi, edukasi, dan pendampingan belajar dengan bermain.
\end{abstract}

Kata Kunci: minat baca, perpustakaan desa, pojok baca purnama

\section{ABSTRACT}

In general, it can be known that the reading interest and reading ability of children in Indonesia is still low when compared to other developing countries. With the problem of low children's reading interest, it is necessary to have a solution for the community, of course for children so that their reading interest is high. In increasing children's interest in reading, the UNISNU Jepara KKN Team Group of 27 Pecangaan Partners chose a program with the Purnama Reading Corner partner, precisely in Gemulung Village RT.03 RW.01 with this reading corner interest program. The 27 KKN Team provided Literacy and Reading Learning Assistance with prizes, Education, and playing so that children's interest in reading increases with the presence of interludes or educational literacy so that learning by playing with the aim of children's reading interest is increasing. Especially during a pandemic like this, children who feel bored with the many tasks given by their teachers. The Purnama Reading Corner is one of the places they visit for reasons so that children don't get bored with school assignments. so it can be concluded that the Purnama Reading Corner program in Gemulung Village is said to be successful because children's interest in reading is increasing with the existence of reading activities with prizes, literacy, education, and learning assistance by playing.

Keywords: interest in reading, village library, purnama reading corner. 


\section{PENDAHULUAN}

Secara umum program Kuliah Kerja Nyata Tematik memiliki tujuan sebagai ajang pembelajaran bersama antara perguruan tinggi (khususnya mahasiswa) bersama masyarakat. Sedangkan secara khusus program Kuliah Kerja Nyata Tematik memiliki tujuan untuk: a) meningkatkan kapasitas dan kompetensi masyarakat melalui upaya-upaya mendidik, melatih, membina dan mendampingi berbagai kelompok/ komunitas masyarakat untuk meningkatkan efektivitas dan produktivitas diri/ kelompok/ komunitas sesuai dengan potensinya masing-masing. b) Belajar dan kerja bersama-sama masyarakat dalam penataan lingkungan dan berbagai sarana sebagai wujud interaksi simbolik antara perguruan tinggi dengan masyarakat setempat (Riyoko dkk., 2021). Salah satu desa yang menjadi lokasi mitra Program Kuliah Kerja Nyata Tematik UNISNU Jepara Mitra Pecangaan adalah Desa Gemulung.

Mitra Pecangaan yang telah dipilih adalah mitra Pojok Baca Purnama yang dikelola oleh pengurus IPNU-IPPNU desa Gemulung. Awalnya, pojok baca ini sangat ramai dikunjungi, bahkan diadakan bimbingan belajar untuk anak-anak SD setempat. Namun karena kurangnya sosialisasi oleh pengurus, pojok baca purnama semakin sepi pengunjung bahkan bisa dibilang mati suri selama dua bulan terakhir ini. Selain itu, fasilitas juga kurang memadahi. Padahal, pada bulan-bulan sebelumnya pojok baca sangat ramai dikunjungi anak-anak bahkan banyak kegiatan yang dilakukan pengurus bersama anak-anak.

Secara garis besar, kemampuan membaca anak Indonesia masih rendah jika dibanding negara lain (Agustina, 2019). Hal ini dikarenakan rendahnya minat baca anak terhadap buku-buku bacaan. Anak lebih tertarik bermain gadget dibandingkan dengan membaca buku. Hal ini tentu akan memberi dampak negatif terhadap minat baca dan kemampuan membaca anak-anak.Hal ini juga dialami oleh anak-anak di Desa Gemulung. Ditambah adanya faktor kurangnya pengawasan orang tua terhadap anak karena mayoritas orang tua menjadi pekerja pabrik, anak-anak menjadi tidak terkontrol dalam pengawasan penggunaan gadget sehingga minat baca anak-anak semakin berkurang (Warsihna, 2016).

Adanya permasalahan tersebut tentunya bisa disiasati dengan memanfaatkan fasilitas desa yang ada, yaitu dengan memanfaatkan pojok baca purnama sebagai jembatan untuk meningkatkan minat baca anak-anak desa gemulung. Karena Pojok Baca dengan fasilitas yang tidak memadai,maka Salah satu yang bisa dilakukan adalah dengan menambah fasilitas pojok baca seperti menambah buku bacaan yang lebih menarik perhatian anak-anak, merenovasi ruangan, dan memberikan literasi, edukasi, dan bermain untuk anak agar anak minat bacanya semakin tinggi.

Menurut Sukardi (1987), ada dua faktor yang dapat mempengaruhi minat baca anak, yaitu faktor yang bersifat konvensional dan faktor yang bersifat non konvensional. Faktor yang bersifat konvensional berkaitan dengan ketersediaaan buku-buku bacaan, penataan dan desain buku, isi buku, ilustrasi, dan cara penyajian buku. Sedangkan faktor yang bersifat non konvensional berkaitan dengan pengenalan dan promosi terhadap koleksi buku. Kegiatan ini bisa dilakukan dengan mengadakan pameran atau sosialisasi pada kegjatan-kegiatan tertentu.

Berdasarkan analisis situasi dan permasalahan di atas, maka tim KKN mitra Pecangaan ingin menghidupkan kembali pojok baca purnama agar bisa difungsikan sebagaimana mestinya. Dibukanya kembali pojok baca purnama diharapkan agar bisa meningkatkan minat baca anak-anak desa gemulung dan bisa dimanfaatkan masyarakat untuk memperoleh pengetahuan dalam hal pendidikan, ekonomi, sosial maupun budaya. Selain itu Tim KKN UNISNU Jepara Mitra Pecangaan memberikan kegiatan Membaca berhadiah, Literasi, Edukasi, dan Pendampingan belajar dengan bermain. Pendampingan belajar kepada anak-anak, sehingga tugas atau materi yang telah diberikan guru bias tersampaikan kepada anak. Karena dalam pembelajaran daring banyak anak dan orang tua yang mengeluh dengan adanya pembelajaran

\section{METODE}

Metode Pelaksanaan yang digunakan untuk memberikan solusi yang dihadapi oleh Pojok Baca Purnama Tim KKN menawarkan pelaksanaan tahapan yang pertama yaitu memebersihkan rumputrumput yang berada dipekarangan kemudian mengecat ulang tembok-tembok agar kelihatan lebih 
fresdan bagus, setelah itu Tim KKN 27 juga membuatkan banner agar warga Gemulung yang lewat bisa mengetahui bahwa dibalai desa ada Pojok Baca.

Tahapan selanjutnya yaitu menghias ruangan Pojok Baca Purnama dengan membuat kerajinan tangan dari koran bekas dan membuat hiasan-hiasan burung, kupu-kupu dan bunga yang warna-warni untuk ditempel maupun digantung diruangan Pojok Baca Purnama, agar ruangannya tidak polos dan lebih menarik saat dikunjungi. Tim KKN 27 juga akan menata ulang buku-buku yang sudah ada, serta mengelompokkan buku-buku sesuai dengan temanya. Tim KKN 27 juga membuka donasi buku untuk menambah koleksi buku di Pojok Baca dan donasi yang Tim KKN 27 buka juga memiliki kriteria yaitu buku cerita untuk anak-anak SD karena minimnya buku cerita yang ada di Pojok Baca Purnama. Terkait usaha menunjang kenyamanan pengunjung Pojok Baca Purnama Tim KKN 27 menambah fasilitas meja, tikar dan air mineral yang bisa digunakan oleh pengunjung.

Setelah renovasi selesai tahapan selanjutnya yaitu mengadakan sosialisasi, dan sosialisasi ini dilakukan dengan beberapa cara yang pertama yaitu sosialisasi dengan dengan ibu-ibu PKK dan perengkat desa kemudian sosialisasi yang kedua yaitu dengan anak-anak yang adad di Desa Gemulungdengan cara mengundang beberapa anak-anak terlebih dahulu dan nanti anak-anak tersebut disuruh mengajak temennya untuk ke Pojok Baca, kemudian sosialisasi dengan tokoh agama yang ada di Desa Gemulung dengan cara ikut ngajar ngaji sekaligus memberitahu anak-anak tentang Pojok Baca Purnama. Tim KKN juga mengadakan kegiatan Bimbingan Belajar yang mana bimbingan belajar tersebut merupakan ajang untuk sosialisasi dengan anak-anak. Selain itu, Tim KKN 27 juga mengadakan sosialisasi dengan remaja-remaja desa gemulung melalui organisasi IPNU-IPPNU, POKDARWIS dan Karang Taruna Desa Gemulung.

\section{PELAKSANAAN DAN PEMBAHASAN}

Kegiatan KKN Tematik Angkatan X dilakukan dalam masa pandemi Covid-19. Tim KKN 27 menerapkan peraturan kesehatan dari pemerintah seperti Memakai masker setiap melakukan kegiatan KKN, Mencuci tangan dengan sabun, dan menjaga jarak. Sebelum kegiatan KKN tematik ini dimulai, ada 5 tahapan yang harus dilakukan untuk melaksanakan program KKN Tematik sesuai dengan yang telah direncanakan.

Pertama, melakukan idenifikasi masalah, identifikasi masalah merupakan bagian dari proses penelitian yang mengawali langkah-langkah penelitian. Seperti yang sudah di jabarkan di latar belakang masalah yang ditemukan pada penelitian ini merupakan masalah kurangnya kesadaran masyarakat Desa Gemulung pada membaca dan kurangnya perhatian masyarakat pada Pojok Baca Purnama yang merupakan salah satu tempat belajar di Desa Gemulung.

Kedua, merencanakan program-program untuk memberikan solusi pada masalah yang ditemukan dilapangan. Program ini direncanakan dengan seluruh anggota Tim KKN kelompok 27 Mitra 1 yang sudah di setujui oleh Dosen Pembimbing Lapangan (DPL). Ketiga, melaksanakan program-program yang telah direncanakan, salah satunya merenovasi ruangan di Pojok Baca PurnamaDesa Gemulung. Karena tempat yang kurang menarik dan kurangnya perawatan membuat Pojok BacaPurnama menjadi kotor dan anak-anak yang belajar di Pojok Baca hanya beralaskan tikar. Namun adanya program KKN Tematik untuk merenovasi ruangan Pojok Baca Purnama maka Tim KKN melaksanakan program tersebut kurang lebih dalam waktu 1 minggu sambil melakukan Donasi untuk mengupdate buku-buku di Pojok Baca. 


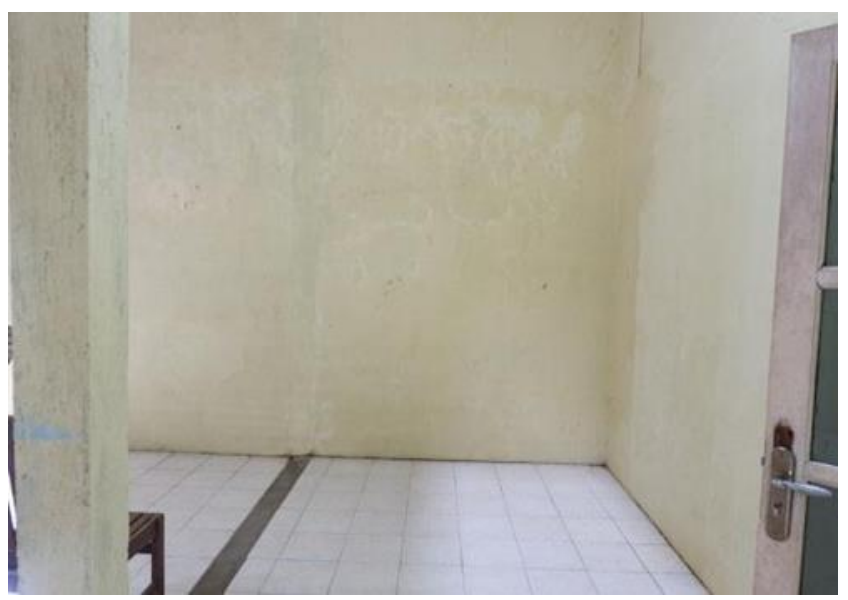

Gambar 1. Pojok Baca Sebelum Direnovasi

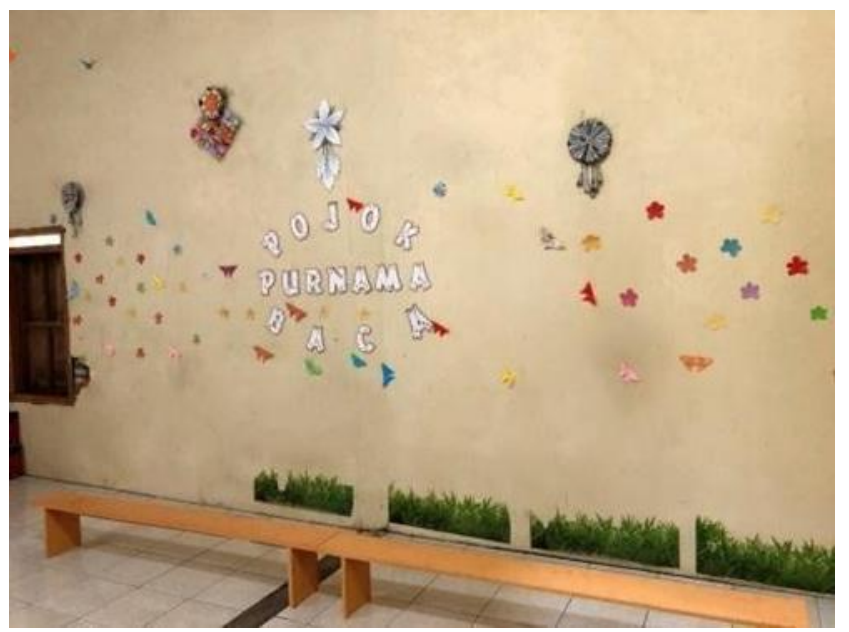

Gambar 2. Pojok Baca Setelah Direnovasi

Keempat, melakukan sosialisasi parenting dengan Ibu-ibu PKK Desa Gemulung, pada masa Pandemi Covid-19 adanya himbauan dari pemerintah seperti belajar dari rumah membuat beberapa lembaga pendidikan tidak dapat melakukan tatap muka. Salah satunya di Desa Gemulung, dengan mayoritas penduduk sebagai buruh pabrik membuat anak-anak tidak dapat menerima pembelajaran dari rumah dengan efektif. Oleh karena itu adanya program dari Tim KKN tentang sosialisasi "Pendampingan Belajar dan Pola Asuh Anak pada Masa Pandemi" dan "Pemanfaatan Kuota Belajar Melalui Aplikasi Rumah Belajar" dari dua kegiatan Sosialisasi ini dapat membantu pemahaman ibuibu di Desa Gemulung tentang pola asuh anak pada masa pandemi dan juga dapat mengajarkan tentang penggunaan aplikasi belajar untuk membantu saat pendampingan belajar pada anak. 


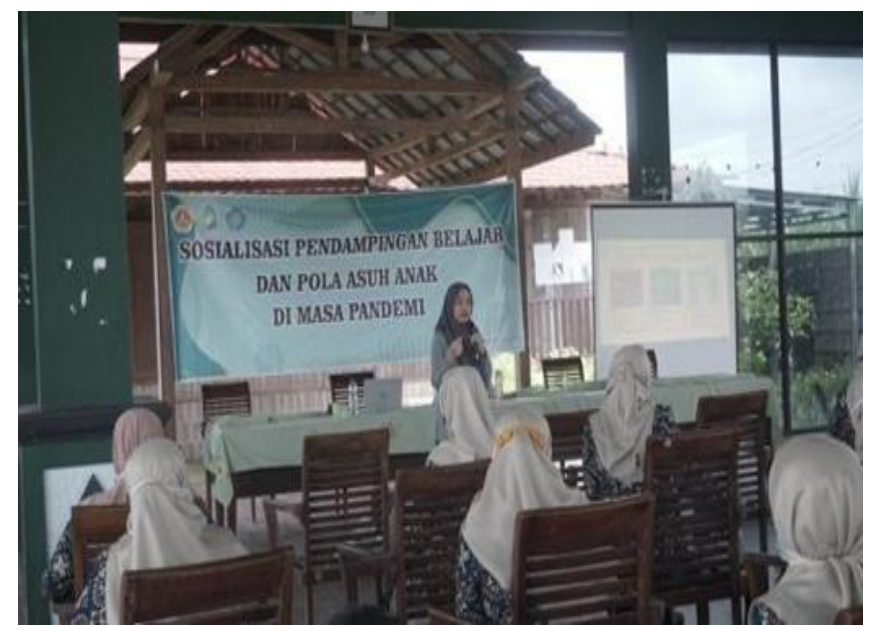

Gambar 3. Sosialisasi Pendampingan Belajar dan Pola Asuh Anak

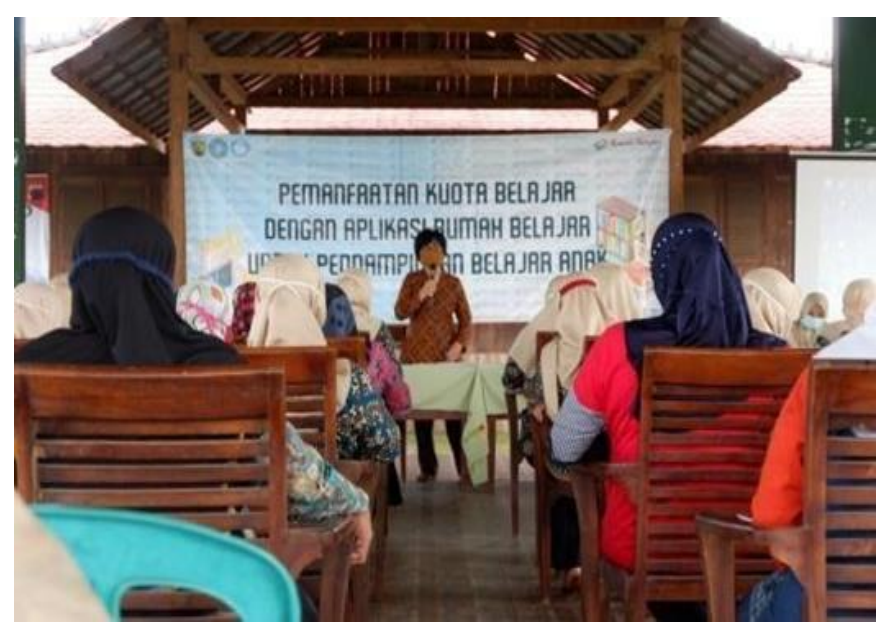

Gambar 4. Sosialisasi Pemanfaatan Kuota Belajar

Kelima, melakukan pendampingan belajar pada anak-anak di Pojok Baca Desa Gemulung dengan mengajarkan beberapa mata pelajaran, mengenalkan permainan tradisional, menonton film, membuat kreasi dari barang bekas dan membuat kreasi masakan. Kegiatan-kegiatan ini dilakukan untuk menarik perhatian anak-anak agar anak-anak merasa nyaman untuk belajar di Pojok Baca.

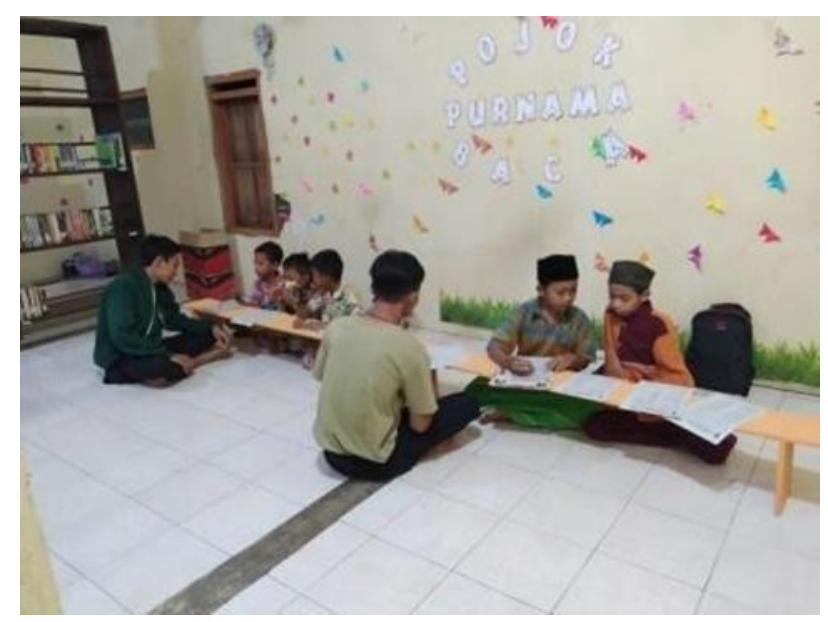

Gambar 5. Pendampingan Belajar 


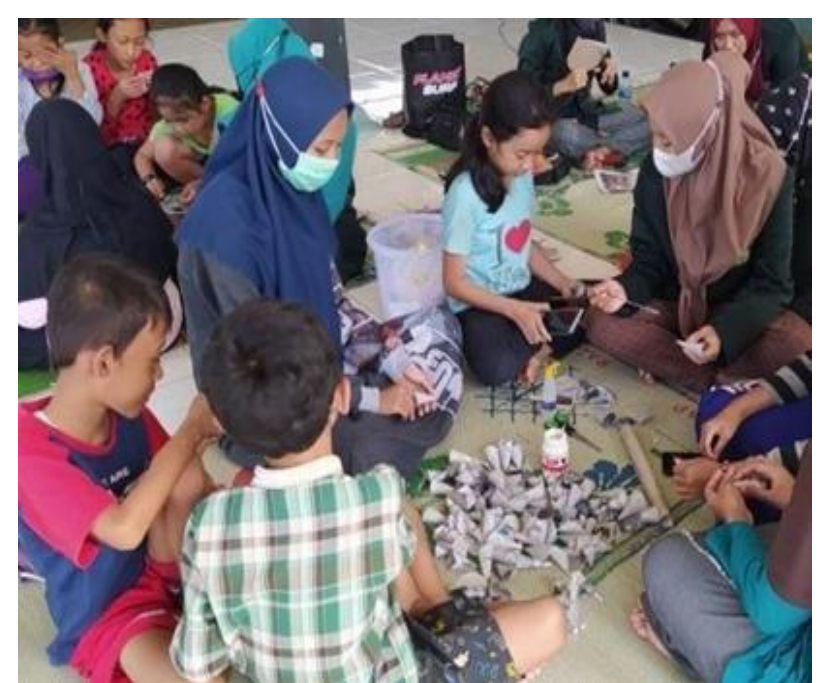

Gambar 6. Membuat Kreasi dari Barang Bekas

\section{SIMPULAN}

Perpustakaan desa merupakan program desa yang di maksudkan untuk meningkatkan dan memperbaiki kulitas sumber daya manusia di desa tersebut, dengan adanya perpustakaan desa ini di harapkan dapat meningkatkan minat baca masyarakat terutama anak-anak, karena dengan membaca dapat menambah pengetahuan anak-anak, seperti kata pepatah membaca merupakan sumber ilmu dan buku adalah jendela dunia. Menanggapi rendahnya minat baca masyarakat terlebih lagi anak anak di desa Gemulung kecamatan pecangaan jepara ini. Dalam pengabdian singkat di desa Gemulung ini kami mengadakan program menghidupkan kembali perpustakaan di desa Gemulung, dan dengan di hidupkannya kembali perpustakaan desa gemulung ini di harapkan dengan program perpustakaan desaini dapat membantu meningkatkan minat baca para anak anak di desa gemulung ini sendiri, selain membantu menghidupkan kembali perpustakaan kami juga mencoba menggalang donasi buku untuk menambah koleksi buku di perpustakaan desa ini dan juga kami membuat program bimbel di pojok baca purnama untuk menarik minta para anak anak untuk datang ke perpustakaan pojok baca purnama, selain itu kami juga mengadakan program baca buku berhadiah dan mengenalkan permainan tradisional untuk para anak anak agar lebih betah di pojok baca purnama.

\section{UCAPAN TERIMAKASIH}

Ucapan terimakasih disampaikan kepada Lembaga Penelitian dan Pengabdian Masyarakat (LPPM) Universitas Islam Nahdlatul ulama Jepara (UNISNU) yang telah memberikan dukungan berupa biaya dan motivasi dalam kegiatan pengabdian ini.

\section{DAFTAR PUSTAKA}

Agustina, L., Arffianto, A., Khalishah, S. H., Indarwati, L., Putri, D. R., El-Majid, S. E., Rahayu, K. S., Nurleli, D. Y., Agung, W., \& Sholihah, I. (2019). Revitalisasi Perpustakaan untuk Meningkatkan Minat Literasi Siswa diSD Muhammadiyah Nuru Ilmi Klaten. Buletin KKN Pendidikan, 1(2), 97-105.

Warsihna, J. (2016). Meningkatkan Literasi Membaca dan Menulis dengan Teknologi Informasi dan Komunikasi (TIK). Kwangsan, 4(2), 67-80.

Riyoko, S., Wibowo, P. A., Shofwan, A., Hudi., Riyadi, A., Sholahuddin, M., \& Widayati, W. (2021). Panduan Kuliah Kerja Nyata Tematik Covid-19 Universitas IslamNahdlatul Ulama Jepara. Jepara: PPKKN dan LPPM.

Sukardi, D. K. (1987). Bimbingan Perkembangan Jiwa Anak. Jakarta: Ghalia Indonesia. 